\title{
In Memoriam: Steven Béla Várdy (1935-2018)
}

Professor of History Dr. Steven Béla Várdy, founding member of the American Hungarian Educators Association (AHEA), passed away on July 23, 2018, in Budapest.

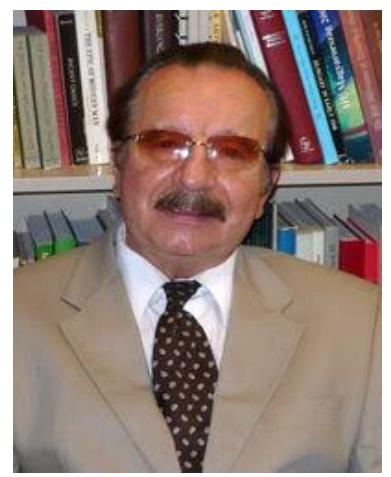

From: all-history-faculty@lyris.duq.edu 〈all-history-faculty@lyris.duq.edu>

Sent: Monday, July 30, 2018 3:53 PM

Subject: It is with deep sadness that we announce the passing of Professor Emeritus and McAnulty Distinguished Professor of History Dr. Steven Béla Várdy

It is with deep sadness that we announce the passing of Professor Emeritus and McAnulty Distinguished Professor of History Dr. Steven Béla Várdy. Dr. Várdy received his doctoral degree from Indiana University and taught at Duquesne University for fifty years - from 1964 to 2014. As one of Duquesne's most prolific faculty members,

Dr. Várdy wrote and edited more than 22 books, 175 scholarly articles, 87 book reviews, 83 encyclopedia entries, 60 essays, and 350 newspaper articles. He was considered one of the world's leading experts in Hungarian history and presented more than 100 conference papers in Europe and the United States. He received numerous awards for his scholarly achievements, including Hungary's Berzsenyi Prize, Hungary's Officers' Cross of the Order of Merit, Árpád Academy's Gold Medal, Canada's Pro Libertate Diploma and Pro Patria in Exteris Diplom a, along with Duquesne University's Excellence in Scholarship Award.

Dr. Várdy was elected to the Hungarian Writer's Federation and the Hungarian Academy of Science; he received two honorary doctorates from Hungarian universities and had two festschrifts written in his honor by some of his former students. Dr. Várdy served on a number of editorial boards and held administrative positions on numerous external academic associations and committees - some of which he founded. 
Dr. Várdy is survived by his wife of 56 years, Dr. Ágnes Huszár Várdy - who co-wrote and co-edited some of his scholarly work - as well as his three children Nicholas, Zoltán, and Laura, and four grandchildren. In 2015, Drs. Agnes and Steven Várdy endowed the Várdy International Research and Study Grant at Duquesne University to support overseas research by graduate history students or study abroad by undergraduate history majors.

John J. Dwyer, PhD

Chair

Department of History

Duquesne University

603 College Hall

Pittsburgh, PA 15282

Email: dwyer@duq.edu

\section{Búcsú Magyar-Amerika történetírójától}

\section{Géza Jeszenszky}

Az 1849-ben levert Szabadságharc óta Amerikában menedéket, munkát talált és megbecsülést szerzett magyarok száma jócskán meghaladja a milliót. Az általuk épített templomok és magyar közösségi házak nagy többségében már nem hallatszik a magyar szó, de emlékük meg van örökítve emléktáblákon, könyvekben - és leszármazottaik szívében. Történetük legalaposabb ismerője, krónikása, a magyar történelem egyik elsőszámú amerikai tolmácsolója, az 1935-ben a Nógrád megyei Bercelen született Várdy Béla 2018. július 23-án Budapesten megtért Teremtőjéhez.

Szüleivel a II. világháború végén hagyta el szülőföldjét, de Amerikában fölnőve és ott tekintélyes egyetemi tanári pályát befutva is magas szinten müvelte anyanyelvét és megörizte magyar tudatát. Az Amerikába kivándorolt magyarok két központjában, Clevelandben és Pittsburghban élt és tanított, ebböl a helyismeretből, meg alapos kutatások révén született meg egyik fö müve, a 2000-ben megjelent, 840 oldalas Magyarok az Újvilágban. De az Óvilágban, az „old country”-ban élö magyarok történetét is alaposan ismerte. Az általa írt vagy szerkesztett könyvek száma 22, ehhez jön 175 tudományos tanulmány, 87 könyvismertetés, valamint többszáz cikk lexikonokban és újságokban, folyóiratokban. Írt egy kitünő összefoglalót a magyar történetírás történetéröl, az 1970-es és 80-as években felhívta az angolul olvasók figyelmét a Kárpát-medence magyar kisebbségeinek súlyos helyzetére, a rendszerváltozás után pedig az elsők között publikált a Szovjetunióba hurcolt, a Gulag-táborokban szenvedő magyar rabok sorsáról.

Az írás mellett tudományszervezőként is sokat alkotott. A pittsburghi Duquesne Egyetemen sok éven át vezette a történelem tanszéket, ott rendszeres konferenciákat szervezett (elsősorban közép-európai témákból, számos magyarországi előadóval), egyik alapítója és többszörös elnöke volt az Amerikai Magyar Történelmi Társulatnak [American Association for 
the Study of Hungarian History; újabb nevén Hungarian Studies Association], az Amerikai Magyar Tanáregyesületnek [American Hungarian Educators Association] és a NyugatPennsylvániai Magyar Kulturális Társaságnak [Hungarian Cultural Society of Western Pennsylvania]. Mindebben társa, több esetben szerző-társa volt felesége, Huszár Ágnes művelődéstörténész és szépíró.

Történetírói elfogulatlansága és irodalmi stílusa mellett életművének meghatározója volt az összmagyarság ügye melletti elkötelezettség. Elutasította a mítoszokat (ld. Kossuthtanulmányai) és leleplezte az embertelenségeket (Ethnic Cleansing in Twentieth-Century Europe). Kollégái és tisztelöi két ízben is köszöntötték tanulmánykötettel, a 2012-esben feleségével együtt.

A számos amerikai elismerés, díj mellé a rendszerváltozás után jött a Miskolci Egyetem díszdoktori címe, a Magyar Köztársasági Érdemrend Tisztikeresztje, 2010-ben pedig a Magyar Tudományos Akadémia külső tagjai sorába választotta.

Béla (Amerikában használt nevén Steven Bela Vardy - mert a „Béla” nevet általában nőnek gondolták) minden körben elismert és kedvelt személyiség és remek barát volt. Otthonuk gyakran adott helyszínt az oda látogatók előadásainak, baráti találkozóknak, feleségemmel együtt én is sokszor élveztem családja vendégszeretetét. Felesége, három gyermeke és négy unokája mellett a barátok és tisztelők sokasága gyászolja.

Jeszenszky Géza ～2018.aug.1.

\section{Elhúnyt Várdy Béla, az MTA külső tagja}

Az amerikai-magyar történészprofesszorra Frank Tibor emlékezik. Várdy Béla 83 éves volt.

2018. augusztus 21 .

Gyásza van a Magyar Tudományos Akadémiának: 83 éves korában elhunyt Várdy Béla (Steven Béla Várdy) magyar-amerikai történészprofesszor, az MTA külső tagja (2010).

A II. világháború végén, gyermekként hagyta el Magyarországot, az 1950-es évek elején került az Egyesült Államokba. Egyetemi tanulmányait a Western Reserve University és a John Carroll University hallgatójaként, illetve a bloomingtoni Indiana Universityn, valamint a Bécsi Egyetemen végezte. 1964-től a pittsburghi katolikus Duquesne Universityn és a University of Pittsburgh oktatójaként is müködött, Kelet-Közép-Európa történetével foglalkozott. Két évet töltött Magyarországon is az MTA Történettudományi Intézete és az Eötvös Loránd Tudományegyetem vendégeként.

Tudományos munkássága elsősorban a magyar történelemre terjedt ki. Mintegy másfél tucat kötetet és majd hatszáz cikket, tanulmányt és egyéb írást tett közzé, igen sok nagy, nemzetközi enciklopédiának is munkatársa volt. Jelentős mértékben járult hozzá, hogy az amerikai és nemzetközi nagyközönség is megismerje a magyar történelmet. Sokat írt a magyar középkorról, a magyar historiográfiáról és müvelődéstörténetről, az amerikai magyarság 
Dwyer, John J., Géza Jeszenszky, Tibor Frank. "In Memoriam: Steven Béla Várdy (1935-2018).” Hungarian Cultural Studies. e-Journal of the American Hungarian Educators Association, Volume 12 (2019) DOI:

történetéről, elsősorban angol nyelven ismertetve a magyarságtudománnyal kapcsolatos kutatásait.

Egy fontos, 840 oldalas tanulmánykötete magyarul is megjelent: a Magyarok az Újvilágban (Az észak-amerikai magyarság rendhagyó története) 2000-ben látott napvilágot a Magyar Nyelv és Kultúra Nemzetközi Társasága kiadványaként. A szerző szavaival ez „lényegében a nagyközönségnek szánt eklektikus szintézis, amely [...] részletesen dokumentálja állításait, s azokat alátámasztja egy nagyméretủ bibliográfiával”.

Még egy lényeges munkája jelent meg magyarul is: feleségével és hüséges munkatársával, Várdy Huszár Ágnessel együtt könyvet írt a „Gulag rabszolgatáboraiban” szenvedett magyarokról (Magyarok a Gulag rabszolgatáboraiban. Budapest: Kairosz, 2007², $2010^{2}$ ), amely kétszer is megjelent magyarul.

Erős, egyenes, tisztességes, őszinte ember volt, mindig készen a segítségadásra. Sok hazai kollégáját támogatta az 1970-es évektől kezdve, meghívással egyetemére, konferenciáira, köteteibe, tanáccsal, forrásokkal, könyvekkel. Amerikában élt, de a magyar történészek közé tartozott. Gyászolja őt a hazai tudományosság is.

Frank Tibor az MTA levelező tagja 